\title{
Testin is a tumor suppressor in non-small cell lung cancer
}

\author{
MING WANG ${ }^{1 *}$, QIAN WANG $^{2 *}$, WEN-JIA PENG ${ }^{3 *}$, JUN-FENG HU $^{1}$, \\ ZU-YI WANG ${ }^{4}$, HAO LIU ${ }^{5}$ and LI-NIAN HUANG ${ }^{1}$ \\ ${ }^{1}$ Department of Respiratory and Critical Care Medicine, Anhui Provincial Key Laboratory of Clinical Basic Research \\ on Respiratory Disease, The First Affiliated Hospital of Bengbu Medical College, Bengbu, Anhui 233004; \\ ${ }^{2}$ Department of Respiration, The People's Hospital of Lingbi, Suzhou, Anhui 234000; \\ ${ }^{3}$ Department of Epidemiology and Health Statistics, Bengbu Medical College, Bengbu, Anhui 233004; \\ ${ }^{4}$ Department of Cardiothoracic Surgery of the First Affiliated Hospital of Bengbu Medical College, Bengbu, Anhui 233004; \\ ${ }^{5}$ Department of Pharmacy, Engineering Technology Research Center of Biochemical Pharmaceuticals, \\ The First Affiliated Hospital of Bengbu Medical College, Bengbu, Anhui 233004, P.R. China
}

Received May 20, 2016; Accepted July 14, 2016

DOI: $10.3892 /$ or.2016.5316

\begin{abstract}
The Testin gene was previously identified in the fragile chromosomal region FRA7G at 7q31.2. It has been implicated in several types of cancers including prostate, ovarian, breast and gastric cancer. In the present study, we investigated the function of the candidate tumor-suppressor Testin gene in non-small cell lung cancer (NSCLC). In NSCLC cell lines, we observed lower expression of Testin compared to that noted in normal human bronchial epithelial cells. MTT assays, flow cytometry, clonogenic assay and invasion assay showed that the overexpression of the Testin gene inhibited cancer cell proliferation, invasion and colony formation. In tumor xenograft models, Testin markedly inhibited lung cancer cell xenograft formation and growth in athymic nude mice. Taken together, these data suggest that Testin plays an important role in the development and progression of NSCLC. Testin may be an effective novel target in NSCLC prevention and treatment.
\end{abstract}

\section{Introduction}

Lung cancer is one of the most common cancers and is a leading cause of mortality worldwide both in males and females. The number of cancer-related deaths expected to occur in 2016 are estimated based on the results obtained from 1998 through 2012

Correspondence to: Professor Li-Nian Huang, Department of Respiratory and Critical Care Medicine, Anhui Provincial Key Laboratory of Clinical Basic Research on Respiratory Disease, The First Affiliated Hospital of Bengbu Medical College, 227 Chang Huai Road, Bengbu, Anhui 233004, P.R. China

E-mail: bbmchln@126.com

*Contributed equally

Key words: non-small cell lung cancer, Testin gene, proliferation, invasion, metastasis as reported to the NCHS at state and national levels. Among males and females, it is the second most commonly diagnosed cancer and the leading cause of cancer-related deaths. In males, lung cancer is expected to account for $14 \%(117,920)$ of the total cases and $27 \%(85,920)$ of all cancer-related deaths in 2016. In females, lung cancer is expected to account for $13 \%(106,470)$ of the total cases and $26 \%(72,160)$ of all cancer-related deaths in 2016 (1). Approximately 80-85\% of the newly diagnosed cases of lung cancer are non-small cell lung cancer (NSCLC). To date, the first-line therapy for advanced-stage NSCLC is chemotherapy. The widespread use of early detection methods and improvements in treatment, such as EGFR-TKIs (erlotinib) (2), gefitinib (3), afatinib (4), anaplastic lymphoma kinase inhibitor (crizotinib) (5), ceritinib (6), alectinib (7), anti-PD-1/PDL-1 immune checkpoint inhibitor (MK-3475) (8), BMS-936558 (9), MPDL3280A (10) have led to a reduction in mortality from lung cancer. Yet, it continues to be the leading cause of cancer-related deaths. Better understanding of the molecules and signaling pathways leading to lung cancer would facilitate the development of more effective treatment strategies, with potential improvements in the quality of life of patients. Thus, identification of novel molecular mechanisms that lead to NSCLC development and progression is still urgently needed.

The Testin gene was previously identified in a common fragile site on chromosome 7q31.2 designated FRA7G. It is a gene encoding a 421 amino-acid protein with three LIM domains. There are three isoforms of human Testin, which differ in the size of the 3'-UTR encoded by exon 7 (11-13). Testin mRNA is expressed in all normal human tissues, while low or lack of Testin expression has been found in prostate cancer, glioblastoma, endometrial carcinoma, ovarian, breast, uterine, colon cancer, esophageal and gastric cancer, acute myelogenous and acute lymphoblastic leukemia (ALL) and nasopharyngeal carcinoma (14-30). Tatarelli et al observed lack of expression in $22 \%$ of cancer cell lines and in $44 \%$ of the cell lines derived from hematological malignancies. In most of these cases the inactivation of Testin expression was due to methylation of a $\mathrm{CpG}$ island. Analysis of the Testin coding region in 26 tumor cell lines revealed three missense mutations (11). Other 
researchers also reported that Testin expression is decreased or silenced partially by hypermethylation and/or loss of heterozygosity in various human cancers $(16,18,26-29)$. Testin is a novel focal adhesion protein with a role in cell spreading. It interacts with a variety of cytoskeletal proteins, including zyxin, mena, VASP, talin, and actin (31-33). Yet, the potential role of Testin in the proliferation, invasion and metastasis of NSCLC is still unknown. The aim of the present study was to examine the relationship between the expression levels of Testin and the proliferation and invasion of NSCLC cells in vitro and tumor growth in NSCLC xenograft models in vivo, in order to conduct a preliminary investigation into whether Testin expression may be a suitable prognostic marker for NSCLC in humans.

\section{Materials and methods}

Cell lines. The NSCLC cell lines LTEP-a-2, A549 and NCI-H1650 were obtained from Anhui Provincial Key Laboratory of Clinical Basic Research on Respiratory Disease, The First Affiliated Hospital of Bengbu Medical College. Human bronchial epithelial cells (16HBE) were purchased from the Type Culture Collection of the Chinese Academy of Sciences, Shanghai, China. The cell lines were cultured in RPMI-1640 supplemented with $10 \%$ fetal bovine serum (FBS) and $0.03 \%$ antibiotic-antimycotic (all from Gibco, Grand Island, NY, USA) at $37^{\circ} \mathrm{C}$ in a $5 \% \mathrm{CO}_{2}$ humidified chamber.

Lentivirus transfection. Cancer cells (A549 and NCI-H1650 cells) were seeded in a 96-well plate at a density of $3 \times 10^{4}$ cells/well. The Testin overexpression vector and the empty vector (Cyagen Biosciences Inc., Guangzhou, China) were used to transfect cells using lentivirus transfection technique according to the manufacturer's protocol to establish Testin overexpression cell lines and control cell lines. The total virus titer is $1 \times 10^{8} \mathrm{TU} / \mathrm{ml}$. The virus titer was diluted with HBSS or RPMI-1640 according to the cell number and the multiplicity of infection. The appropriate multiplicity of infection was 40. Furthermore, Polybrene (Sigma-Aldrich, St. Louis, MO, USA) was used to significantly increase the viral transfection efficiency, which plays an important role in the lentivirus transfection.

Semi-quantitative PCR analysis. Total RNA was extracted with TRIzol reagent (Invitrogen Life Technologies, Carlsbad, CA, USA) according to the manufacturer's instructions. Total RNA was reverse transcribed to cDNA in a $20 \mu 1$ volume using a reverse transcription kit (Invitrogen Life Technologies). Isoform 2 was used to design the PCR primers. Primers designed and utilized for Testin were: forward, 5'-ACTGTGGC AGACATTACTGTGACA-3' and reverse, 5'-GATAGCTATG GCTCGATACTTCTGGGTGC-3'. The length of the Testin primer was $440 \mathrm{bp}$. $\beta$-actin was used as an endogenous control for quantitative DNA-PCR. Primers designed and utilized for $\beta$-actin were listed as follows: forward, 5'-TCACCAACTGGG ACGACAT-3' and reverse, 5'-GCACAGCCTGGATAGC AAC-3'. The length of the $\beta$-actin primer was $192 \mathrm{bp}$. Annealing was performed at $72^{\circ} \mathrm{C}$ for Testin. All PCR product electrophoreses were performed on a $2 \%$ agarose gel with ethidium bromide and visualized using the Gel Imager system
(Asia Xingtai Mechanical and Electrical Equipment Co., Beijing, China). The relative expression value of Testin mRNA is expressed as the ratio between the target mRNA gray scale value and the $\beta$-actin gray scale value. The experiments were repeated in triplicate to confirm the findings.

Western blot analysis. Proteins were extracted using RIPA lysis buffer (Beyotime, China) containing 0.1\% phosphatase inhibitor cocktail and protease inhibitor. The protein concentrations were determined using the BCA protein assay kit (Beyotime, China). Equal amounts of protein were separated by SDS-PAGE (Amresco, LLC, Solon, OH, USA), electrotransferred to PVDF membranes (Biosharp, China) and blocked in $5 \%$ non-fat dry milk.

The membranes were incubated overnight at $4^{\circ} \mathrm{C}$ with the following primary antibodies: polyclonal goat anti-Testin (sc-34737; 1:50; Santa Cruz Biotechnology, Inc., Santa Cruz, CA, USA) and monoclonal mouse anti- $\beta$-actin (ab8226; 1:2,000; Abcam, Cambridge, MA, USA) as control. Then, the membranes were washed with Tris-buffered saline and Tween-20 (TBST) for three times, and incubated with a 1:2,000 dilution of HRP-conjugated secondary antibodies: rabbit anti-goat IgG (ab6741; Abcam) and goat anti-mouse IgG (ab97023; Abcam) at room temperature for $1 \mathrm{~h}$. The immunoblots were visualized using a chemiluminescence detection kit (Pierce Chemical Co., Rockford, IL, USA).

Flow cytometric analysis. Cells were seeded in a 6-well plate $\left(1 \times 10^{4}\right.$ cells/well) and incubated in $3 \mathrm{ml}$ RPMI-1640 medium supplemented with $10 \% \mathrm{FBS}$ in $5 \% \mathrm{CO}_{2}$ at $37^{\circ} \mathrm{C}$. As the cells grew to the logarithmic phase of growth, the cells in the 6-well plates were collected by digestion with $1 \mathrm{ml} 0.25 \%$ trypsin. After being washed with pre-cooled phosphate-buffered saline (PBS) twice, the cells were re-suspended in $300 \mu 1$ binding buffer and mixed with $5 \mu \mathrm{l}$ Annexin V-PE/7-AAD and $5 \mu \mathrm{l}$ propidium iodide successively, followed by incubation at room temperature in the dark for $15 \mathrm{~min}$. The apoptosis rate of the cells was detected on a flow cytometer within $1 \mathrm{~h}$ according to the manufacturer's instructions.

Cell proliferation assay. The MTT assay was used to assess cellular proliferation. Cells were seeded in a 96 -well plate at a density of $2 \times 10^{4}$ cells/well. Then the cells were incubated in $5 \% \mathrm{CO}_{2}$ at $37^{\circ} \mathrm{C}$ for $72 \mathrm{~h}$. As the cells grew to $80 \%$ confluence, the freshly prepared MTT solution $(5 \mathrm{mg} / \mathrm{ml})$ was added to each well ( $20 \mu \mathrm{l} / \mathrm{well})$, and then incubated for an additional $2 \mathrm{~h}$. Subsequently, the supernatant was removed from the well and $150 \mu \mathrm{l}$ DMSO was added. After shaking, the asorbance of each well at $490 \mathrm{~nm}$ was measured using a microplate reader.

Clonogenic assay. The survival and proliferation potential of the cells were assessed using clonogenic assays. The cells were trypsinized, counted, and seeded in a $6-\mathrm{cm}$ plate at 500 cells/well. After incubation for 2 weeks, the colonies were fixed with paraformaldehyde and stained with Giemsa staining solution, and the number of colonies containing more than 50 cells was scored.

Invasion assay. Six hundred microliters of balanced mixture of the conditional medium from Matrigel fibroblasts and the 

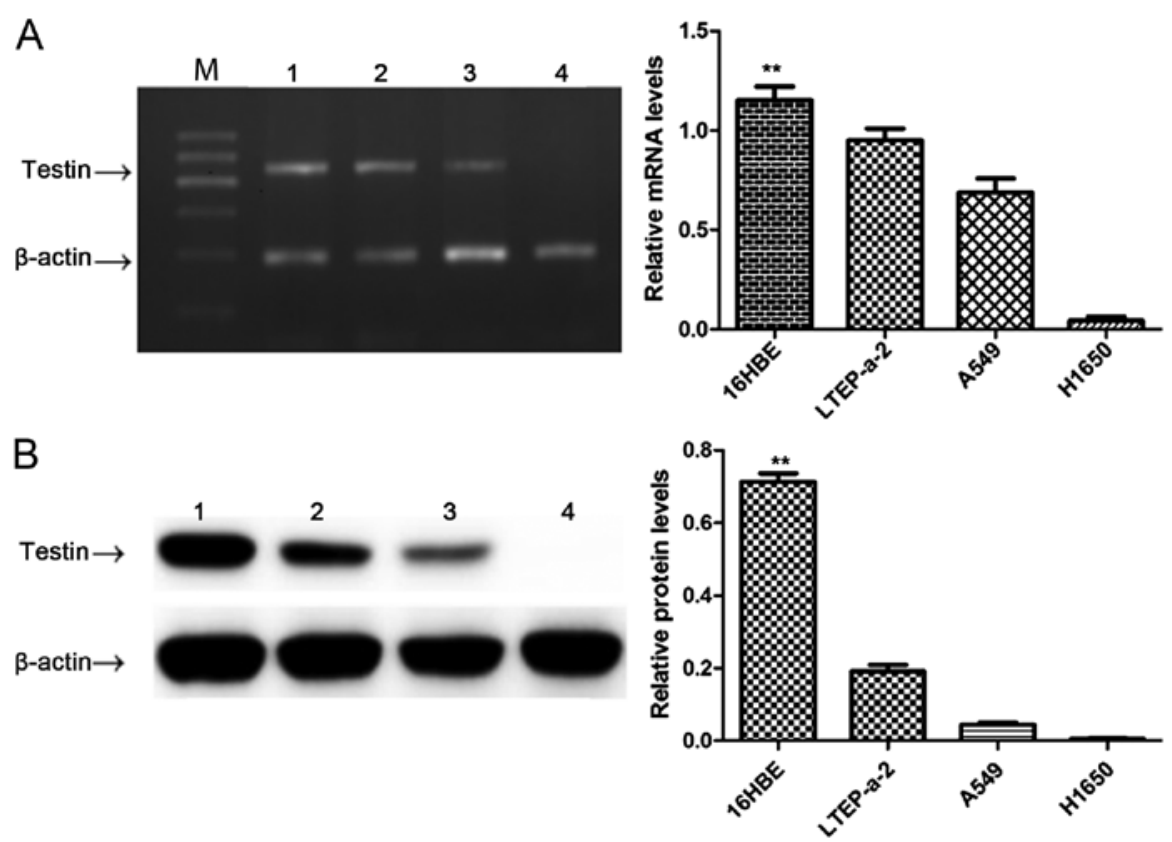

Figure 1. Expression of the Testin gene in lung cancer LTEP-a-2, A549 and H1650 cells and human bronchial epithelial 16HBE cells. (A) Testin mRNA as detected by semi-quantitative PCR. (B) Testin protein as detected by western blot analysis. Lane M, DNA marker; lane 1, 16HBE cells; lane 2, LTEP-a-2 cells; lane 3, A549 cells; lane 4, H1650 cells. Data are presented as means $\pm \mathrm{SD},{ }^{* * *} \mathrm{P}<0.01$ compared with lung cancer cells.

complete medium was added to the lower compartment as the chemotactic factor. Serum-free RPMI-1640 with $1 \times 10^{5}$ cells was added to the upper compartment of the chamber. At the indicated time, the non-invasive cells in the upper compartment were removed with a cotton swab. The cells in the lower compartment of the chamber were counted under a light microscope for a minimum of 10 random visual fields.

In vivo tumor xenograft models. Four-week old female BALB/c athymic nude mice (Comparative Medicine Centre of Yangzhou University, China) were housed in an environmentally controlled room $\left(22 \pm 2^{\circ} \mathrm{C}, 40-60 \%\right.$ humidity and a 12-h light cycle). Cancer cells $\left(1 \times 10^{6}\right)$ were subcutaneously inoculated into the fossa axillaris of mice at 5 weeks of age. The injection was made through the subcutaneous layer of the cervicodorsal part of the animals. The growth of primary tumors was monitored by measuring the tumor diameters for 5 weeks. Tumor length (L) and width (W) were measured twice a week using a caliper, and tumor volume $(\mathrm{V})$ was calculated by the equation: $\mathrm{V}=\left(\mathrm{W}^{2} \mathrm{xL}\right) / 2$. After 5 weeks, the mice were scarificed under anesthesia, the tumor masses were removed, weighed and fixed in $10 \%$ neutral buffered formaldehyde solution and paraffin-embedded for histological analysis or preserved at $-80^{\circ} \mathrm{C}$.

Immunohistochemistry. Tumor sections $(3-\mu \mathrm{m})$ were cut from formalin-fixed paraffin-embedded blocks and mounted on positive-charged slides. The primary antibody was goat anti-Testin polyclonal antibody (Santa Cruz Biotechnology). The paraffin sections were placed in a xylene bath for $10 \mathrm{~min}$ to remove paraffin, and repeated again and then placed in an ethanol gradient for rehydration. Antigen retrieval was performed with EDTA ( $\mathrm{pH}$ 8.0) repair solution in a microwave, cooled to room temperature, treated with $3 \% \mathrm{H}_{2} \mathrm{O}_{2}$ for $10 \mathrm{~min}$ for inactivation of endogenous peroxidase, rinsed with
1X PBST (0.1\% Tween), incubated with 5\% rabbit serum at room temperature for $15 \mathrm{~min}$, and then incubated with primary antibody (1:100) at $4^{\circ} \mathrm{C}$ overnight. The sections were then rinsed and incubated with biotin-labeled secondary antibody (SP KIT; Beijing Zhongshan Golden Bridge Biotechnology Co., Ltd., Beijing, China) at $37^{\circ} \mathrm{C}$ for $15 \mathrm{~min}$, rinsed in $1 \mathrm{X}$ PBST ( $0.1 \%$ Tween) and then incubated with horseradish peroxidase (SP KIT; Beijing Zhongshan Golden Bridge Biotechnology Co., Ltd.) at $37^{\circ} \mathrm{C}$ for $15 \mathrm{~min}$. The sections were then treated with DAB for $10 \mathrm{~min}$ and the reaction was terminated. H\&E staining was performed. The sections were fixed with hydrochloride ethanol and then mounted for analysis. All sections were observed in at least five areas at a magnification of $x 400$ by at least two investigators in a blinded manner. Cytoplasm and nuclei were counterstained with hematoxylin solution. The total number of cells and positive cells were counted and the staining was scored as the percentages of positive cells: 0 (no staining) for specimens with positive cells $\leq 5 \%$; 1 (weak staining) for specimens with positive cells $>5 \%$ and $\leq 25 \% ; 2$ (moderate staining) for specimens with positive cells $>25 \%$ and $\leq 50 \% ; 3$ (strong staining) for specimens with positive cells $>50 \%$. Specimens with scores of $\leq 1$ were regarded as negative; specimens with scores of $>1$ were regarded as positive.

Statistical analysis. Data are expressed as the mean and standard deviation (SD), and statistical analysis was performed using software SPSS version 18.0. The differences among groups were analyzed by one-way ANOVA followed by Bonferroni's multiple comparison test. Differences were considered significant at $\mathrm{P}<0.05$.

\section{Results}

Testin MRNA and protein are reduced in the NSCLC cell lines. In order to clarify the relationship between Testin and NSCLC, 


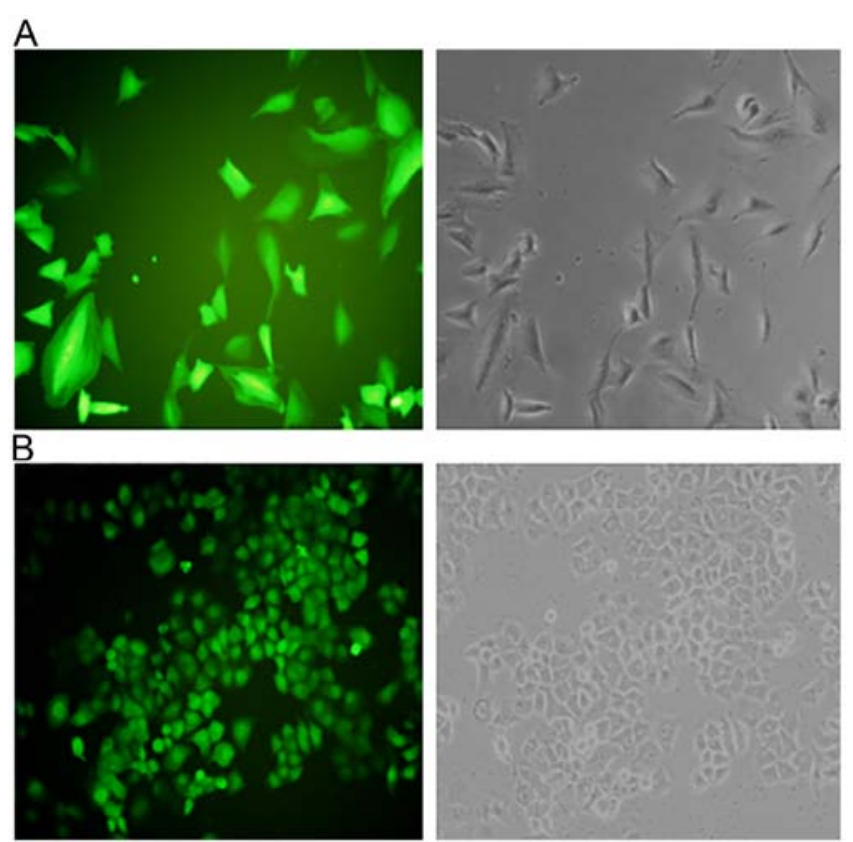

Figure 2. Overexpression of the Testin gene in lung cancer (A) A549 and (B) NCI-H1650 cells (magnification, $\mathrm{x} 400$ ). we first compared the expression level of Testin in NSCLC cell lines LTEP-a-2, A549 and NCI-H1650 and 16HBE cells by semi-quantitative PCR and western blot analysis. The Testin mRNA (Fig. 1A) and protein levels (Fig. 1B) were significantly reduced in the LTEP-a-2, A549 and NCI-H1650 cells compared with these levels in the $16 \mathrm{HBE}$ cells $(\mathrm{P}<0.01)$, suggesting an association between decreased expression of Testin mRNA and protein levels and the carcinogenesis of NSCLC.

Testin gene inhibits proliferation, invasion and colony formation of NSCLC cells and induces cancer cell apoptosis. In order to explore additional functions of Testin in NSCLC, we used the NSCLC cell lines A549 and NCI-H1650 to establish stable cells that constitutively overexpressed the Testin mRNA and protein (Fig. 2). The transfection efficiency was confirmed using semi-quantitative PCR (Fig. 3A)and western blot analysis (Fig. 3B). A549 and NCI-H1650 cells transfected with the Testin overexpression vector showed significantly increased Testin mRNA levels and protein expression compared with the control cells.

We next investigated the effect of Testin overexpression on cell proliferation. The MTT assay showed that
A
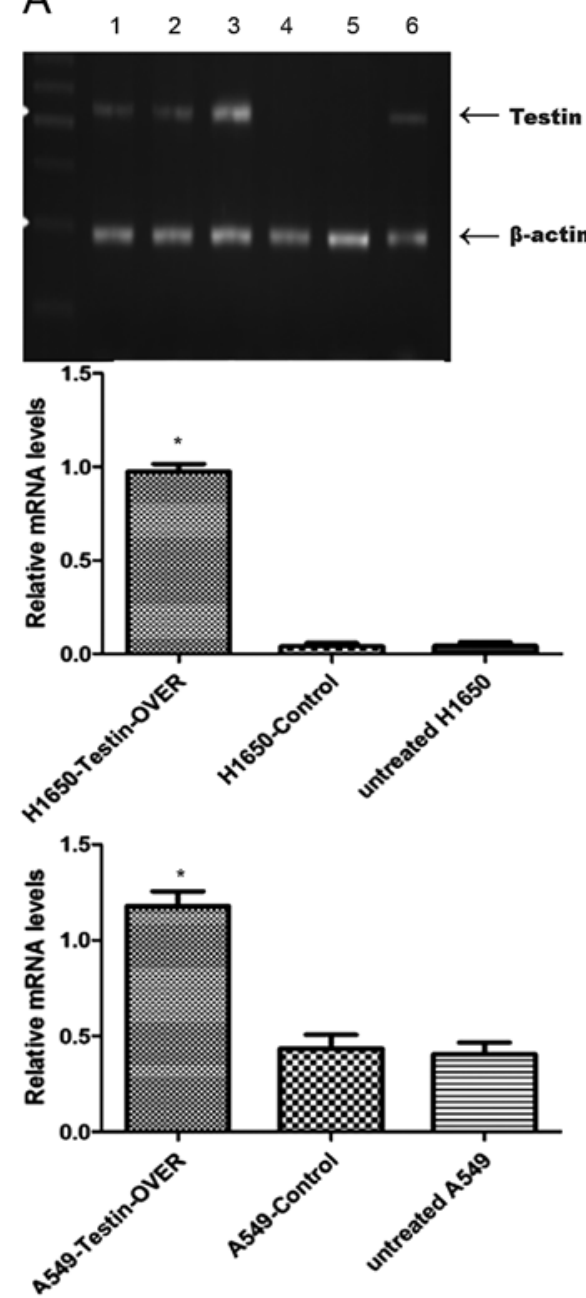

B
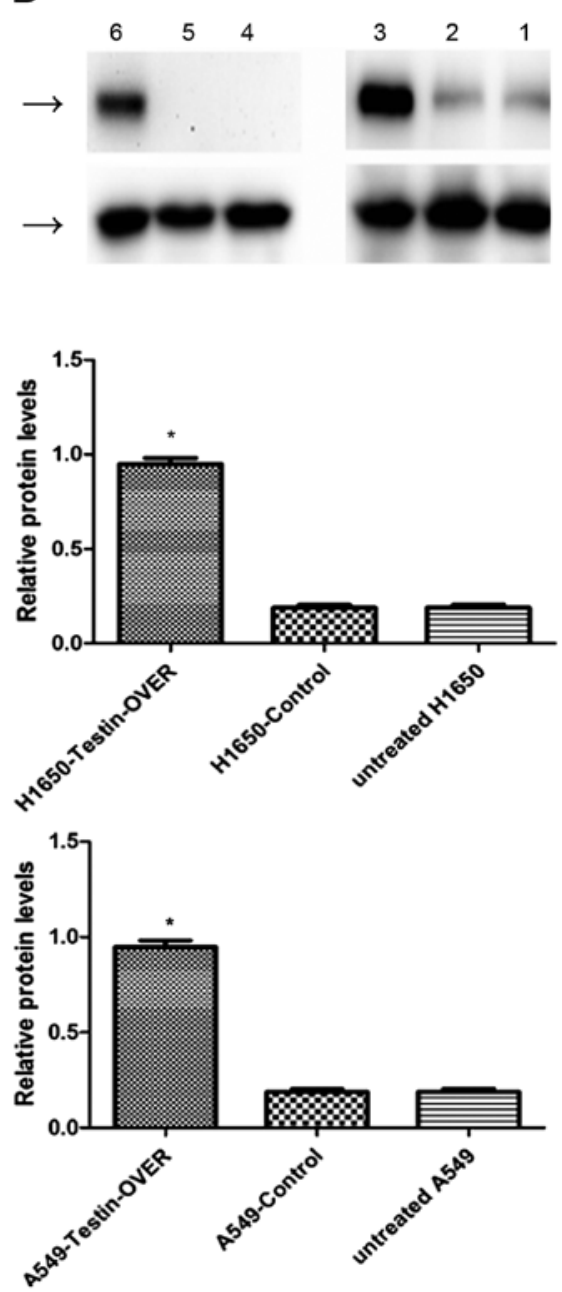

Figure 3. Overexpression of the Testin gene in lung cancer cell lines. (A) Transfection efficiency of Testin mRNA levels measured by semi-quantitative PCR. (B) Transfection efficiency of Testin protein levels measured by western blot analysis. Lane 1, untreated A549 cells; lane 2, A549-control; lane 3, A549-Testin-OVER; lane 4, untreated H1650 cells; lane 5, H1650-control; lane 6, H1650-Testin-OVER. Data are presented as means \pm SD, ${ }^{*}<0.05$ compared with untreated A549 and A549-control. 

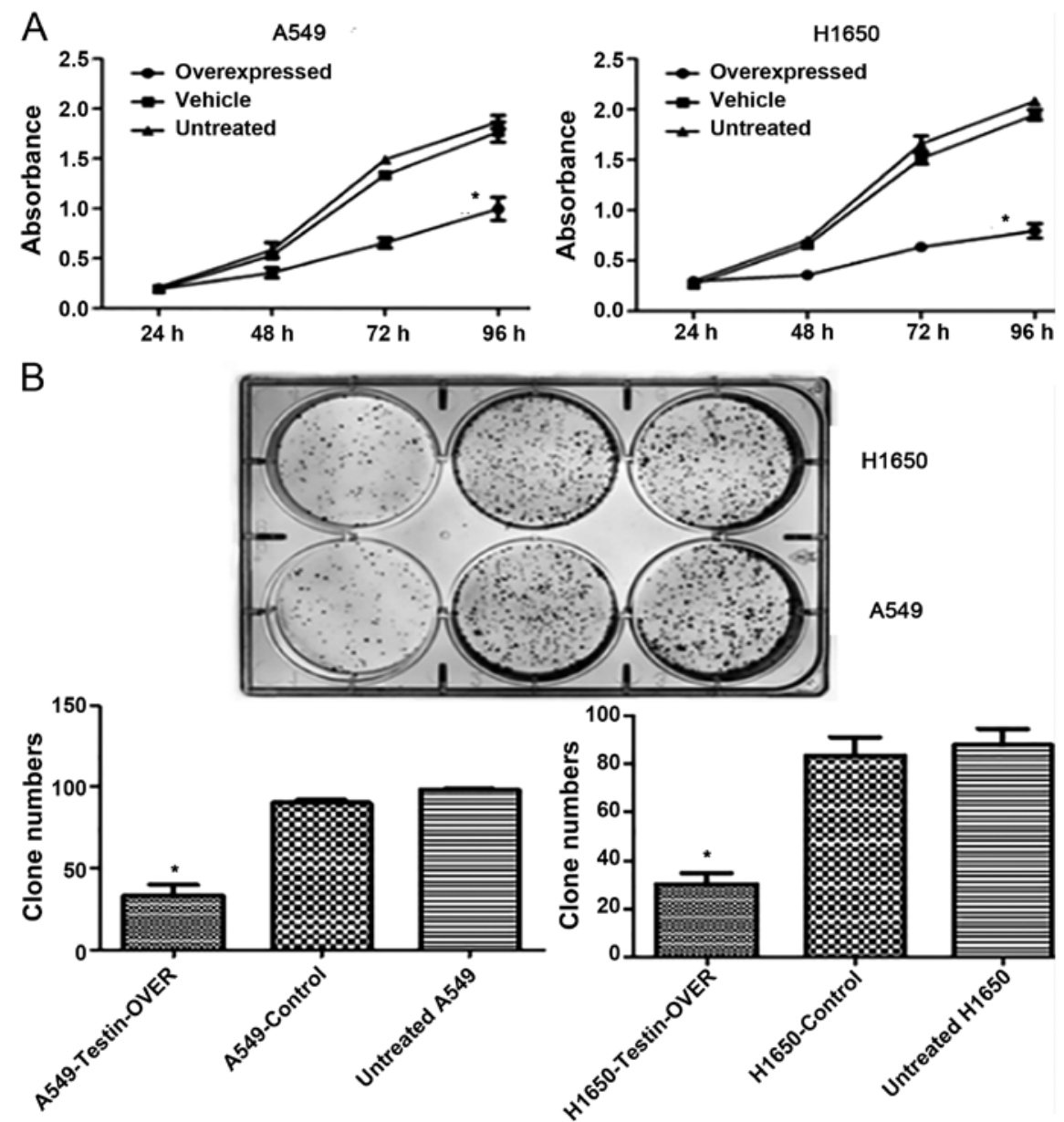

Figure 4. Effect of the Testin gene on the proliferation, colony formation, invasion and apoptosis of lung cancer A549 and H1650 cell lines. (A) Effect of Testin gene overexpression on the proliferation of the control and Testin-transfected lung cancer A549 and H1650 cell lines. (B) Results of the colony formation for the control and Testin-transfected lung cancer A549 and H1650 cell lines. Data are presented as means \pm SD, ${ }^{\text {P }}<0.05$ compared with untreated A549 and A549-control.

overexpression of Testin significantly inhibited proliferation of the A549 and NCI-H1650 cells compared with control cells $(\mathrm{P}<0.05)$ (Fig. 4A). Clonogenic assay showed that overexpression of Testin in the A549 and NCI-H1650 cells markedly reduced colony formation efficiency compared with the control cells $(\mathrm{P}<0.05)$ (Fig. 4B). Invasion assay showed that overexpression of Testin significantly inhibited invasion of the A549 and NCI-H1650 cells compared with the control cells $(\mathrm{P}<0.05)$ (Fig. 4C). Flow cytometric analysis showed that overexpression of the Testin gene in the A549 and NCI-H1650 cells significantly induced cancer cell apoptosis compared with the control cells $(\mathrm{P}<0.05)$ (Fig. 4D). These results suggest that Testin plays a significant role in inhibiting the proliferation, invasion and colony formation of NSCLC cells.

Testin gene inhibits NSCLC cell xenograft formation and growth in vivo. In order to investigate the tumor-suppressing function of Testin in vivo, the Testin-overexpressing A549 cells (A549-Testin-OVER), A549-Control cells and untreated A549 cells $\left(1 \times 10^{6}\right)$ were subcutaneously inoculated into the fossa axillaris of 5-week-old female BALB/c athymic nude mice. During the process, we found that the mice injected with the A549-Testin-OVER cells formed tumors later than those in the control groups. Whereas large tumors were formed in the mice injected with the control cells within 5 weeks, tumor growth was greatly reduced in the mice injected with the A549-Testin-OVER cells (Fig. 5A).

After sacrifice at 5 weeks, the tumor masses were removed, weighed and fixed in $10 \%$ neutral buffered formaldehyde solution. Tumors were stained for Testin and representative images are shown in Fig. 5B. The A549-Testin-OVER group $(98.32 \pm 1.76 \%)$ had higher Testin expression while the A549-control $(22.92 \pm 21.46 \%)$ and untreated A549 group $(20.14 \pm 22.5 \%)$ had lower Testin expression $(\mathrm{P}<0.05)$. These data showed that Testin plays a critical role in the inhibition of NSCLC cell xenograft formation and growth in vivo.

\section{Discussion}

It has been established that Testin is a candidate human tumor-suppressor gene in several types of cancers, including prostate, ovarian, breast and gastric cancer. But its role in NSCLC remains unknown. Our study is the first attempt to elucidate the tumor-suppressor role of Testin in the proliferation, invasion and colony formation of NSCLC cells in in vitro models and in the inhibition of NSCLC cell xenograft formation and growth in in vivo models. Testin encodes 

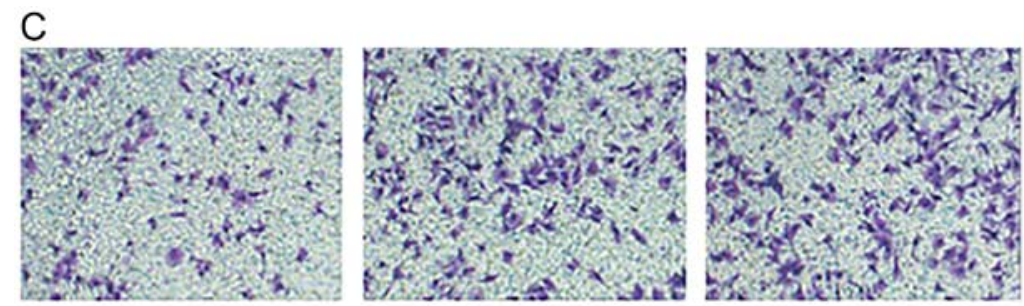

A549-Testin-OVER

A549-Control

Untreated A549
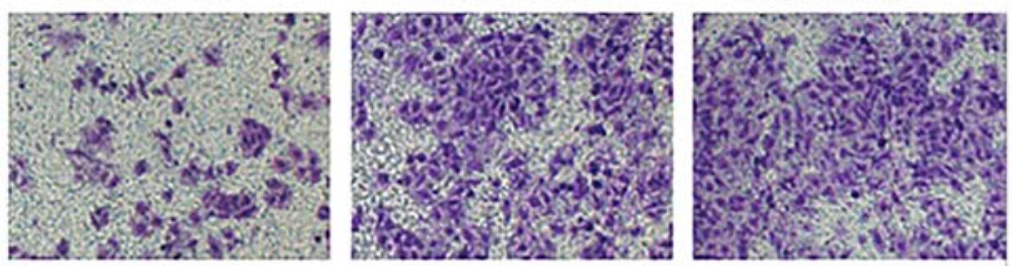

H1650-Testin-OVER

H1650-Control

Untreated $\mathrm{H} 1650$
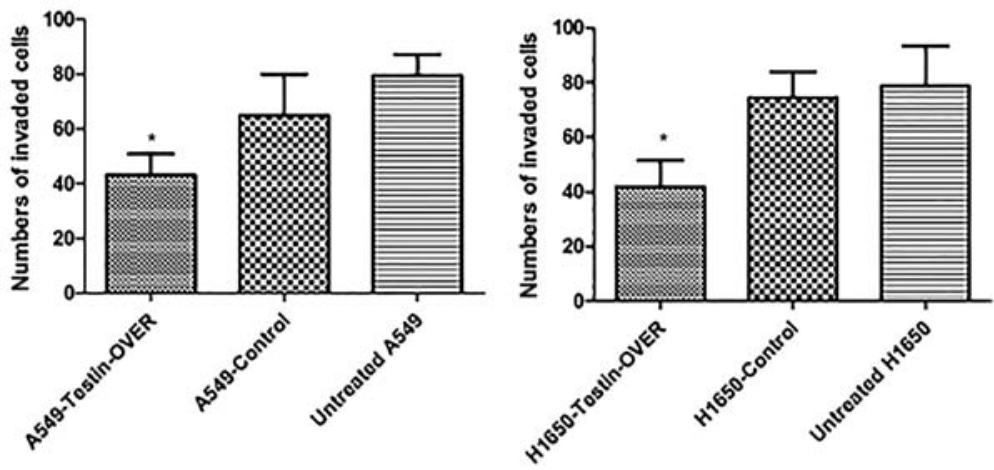

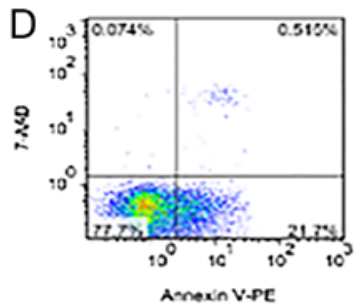

A549-Testin-OVER

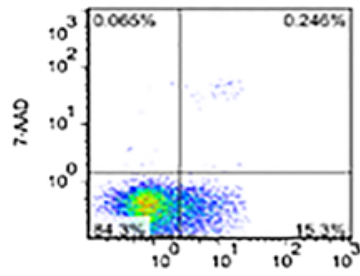

Amexin V.PE

H1650-Testin-OVER

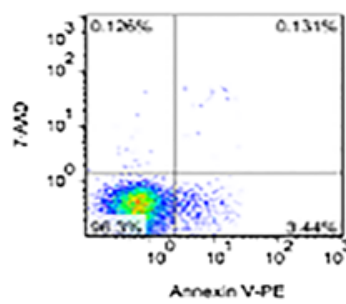

A549-Control

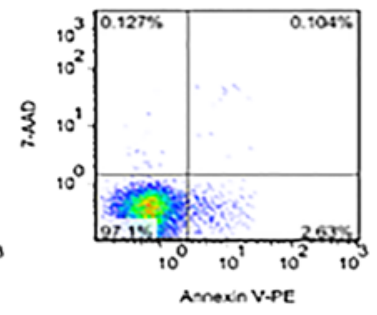

H1650-Control

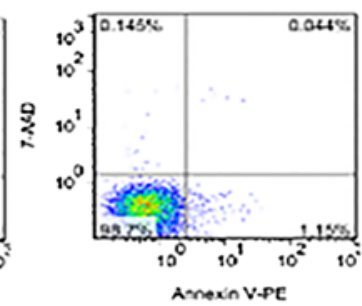

Untreated A549

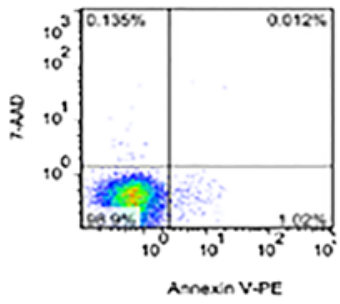

Untreated $\mathrm{H} 1650$
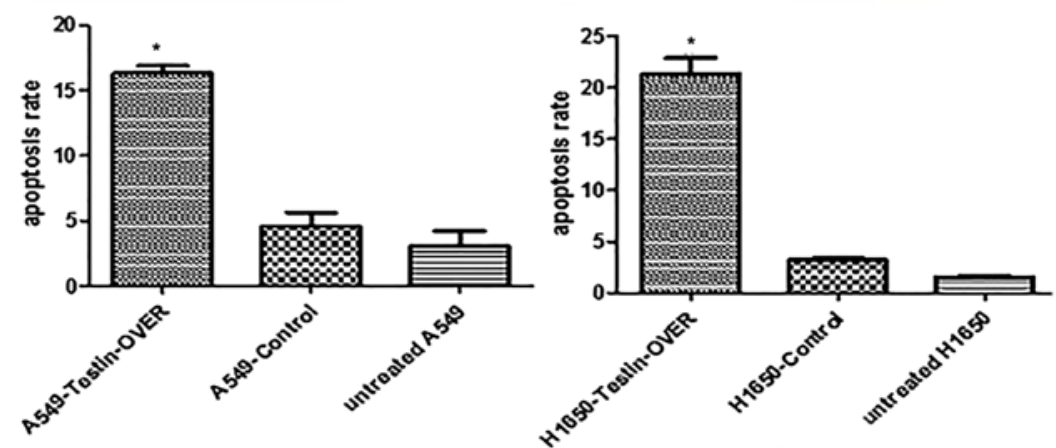

Figure 4. Continued. (C) Effect of the overexpression of the Testin gene on the invasion of the control and Testin-transfected lung cancer cell lines (magnification, $x 100$ ). (D) The cell apoptosis rate of the control and Testin-transfected lung cancer cell lines as analyzed by flow cytometry. Data are presented as means $\pm \mathrm{SD},{ }^{*} \mathrm{P}<0.05$ compared with the untreated A549 and A549-control. 

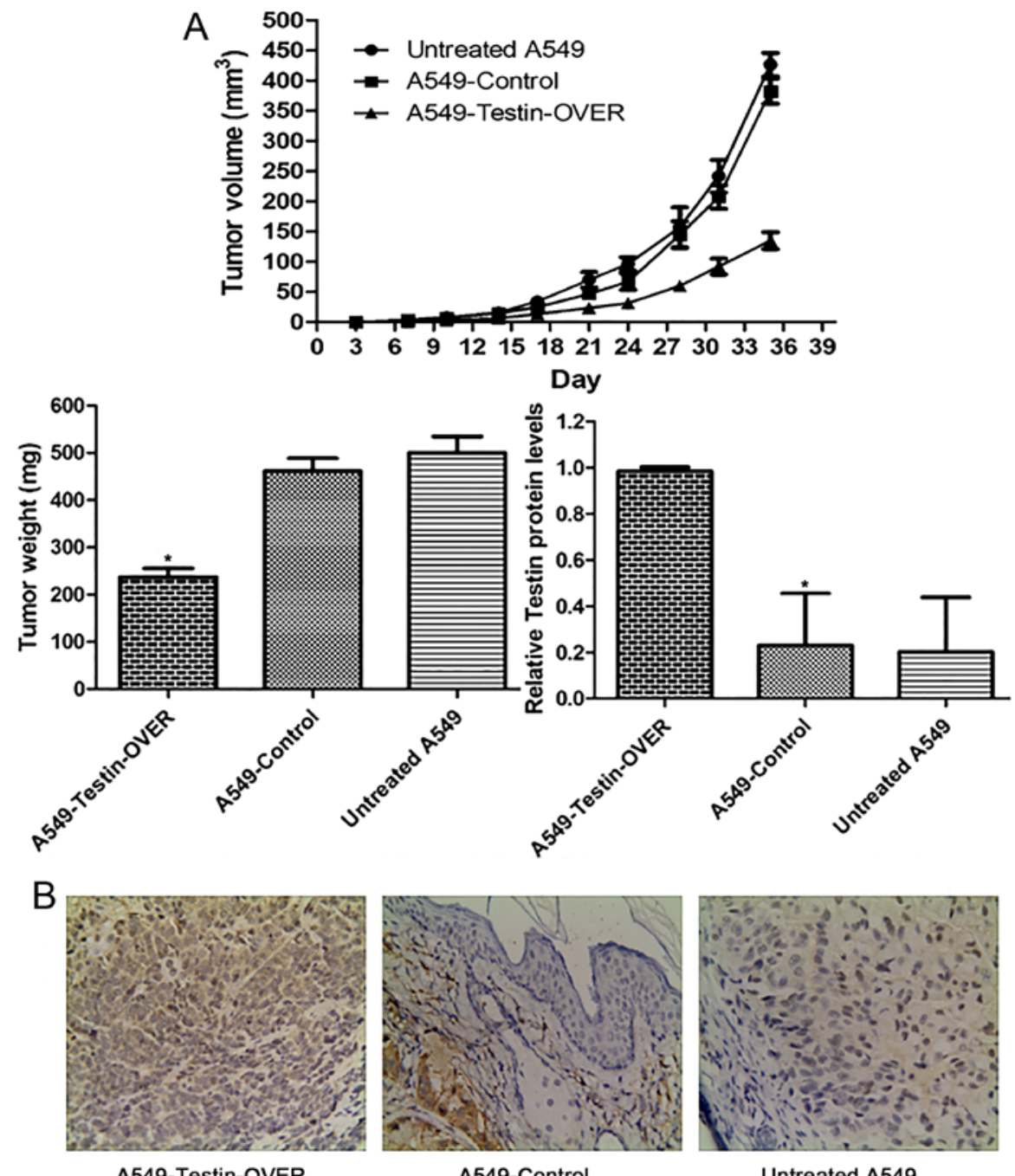

Figure 5. Inhibition of lung cell xenograft formation and growth. (A) The tumor volume, weight and the expression of Testin protein in tumor tissues were plotted. (B) Tumors were stained for Testin and representative images of the A549-Testin-OVER group with high Testin expression and control groups with low Testin expression are shown (magnification, $\mathrm{x} 400$ ). Data are presented as means $\pm \mathrm{SD},{ }^{*} \mathrm{P}<0.05$ compared with untreated A549 and A549-control.

a protein containing a PET domain at the NH2-terminus, which is involved in protein-protein interactions, and three LIM domains at the $\mathrm{COOH}$-terminus. The LIM domain is also a common protein-protein interaction motif that was originally discovered in the products of the lin-11, Isl-1, and mec-3 genes (34-37). One LIM domain consists of a loosely conserved cysteine-rich consensus sequence including two separate zinc fingers. Testin protein can also be a component of focal adhesions and cell junctions, which can interact with other cytoskeleton-associated proteins, such as talin, mena, vasodilator-stimulated phosphoprotein, and actin. Previous studies demonstrated that Testin inhibited the growth of breast and uterine as well as ovarian cancer cell proliferation through caspase-dependent and caspase-independent apoptosis $(18,19)$. Downregulation of Testin has been reported to have a significant association with highly aggressive breast tumor subtypes, such as triple-negative and luminal B tumors, along with the prognostic relevance of nuclear expression of survivin (30). Weeks et al discovered that $100 \%$ of the ALL samples $(n=20)$ were methylated at the Testin promoter, whereas the matched remission $(n=5)$, normal bone marrow $(n=6)$ and normal PBL $(n=5)$ samples were unmethylated. Expression of Testin in hyperdiploid, TEL-AML ${ }^{+}$,

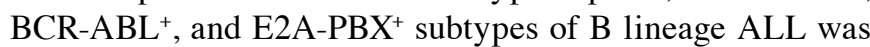
markedly reduced compared to that in normal bone marrow progenitor cells and in B cells. In addition, Testin methylation and silencing was demonstrated in 9 out of 10 independent B ALL propagated as xenografts in NOD/SCID mice. Thus, Testin is the most frequently methylated and silenced gene yet reported in ALL (25). Zhu et al further confirmed that the Testin gene inhibited invasion, metastasis, and angiogenesis through miR-29b-mediated MMP-2 inhibition in breast cancer (22).

In the present study, firstly we identified that Testin expression was reduced in NSCLC cell lines LTEP-a-2, A549 and NCI-H1650 compared with that in 16HBE cells, which implied that Testin is a candidate tumor-suppressor gene in NSCLC. Secondly, to further explore the detailed tumorsuppressor function of Testin, we used the NSCLC cell lines A549 and NCI-H1650 to establish stable cells that constitutively overexpressed the Testin mRNA and protein. The transfection efficiency was confirmed using semi-quantitative PCR and 
western blot analysis. We found that overexpression of Testin significantly inhibited proliferation, invasion, and colony formation in NSCLC cell lines. In tumor xenograft models, Testin also markedly inhibited lung cancer cell xenograft formation and growth. These data further support the tumor suppressor role of Testin in NSCLC. These findings imply that Testin is possibly an individual therapeutic target for NSCLC patients. These results require further validation in larger cohorts. Our present results further confirmed that Testin could significantly inhibit cancer cell proliferation and invasion, but the possible suppressing mechanism of Testin gene and its role in angiogenesis of lung cancer are still unknown. Angiogenesis has been reported to be essential for tumor metastasis (38), thus in subsequent studies we will examine the effect of Testin on angiogenesis, which partly contributes to the metastasis of NSCLC. Furthermore, Ki-67 is a nuclear located protein that is closely linked to cell proliferation. It is present in all active phases of the cell cycle, but absent from resting cells, thus, indicating the proliferating cell fraction (39). Ki-67 is a prognostic biomarker in several tumor entities, for example, breast cancer, lymphoma, neuroendocrine neoplasia and NSCLC (40-45). The Ki-67 index could also be employed to investigate the association between Testin expression and NSCLC cell proliferation.

To the best of our knowledge, this is the first study to indicate the potential role of Testin in the occurrence and development of NSCLC. Expression of Testin was generally lower in NSCLC cell lines compared with that noted in human bronchial epithelial cells. Our findings showed that Testin plays a significant role in the proliferation, invasion and colony formation of NSCLC cells and in the inhibition of NSCLC cell xenograft formation and growth. Testin is a potential therapeutic target for NSCLC patients.

\section{Acknowledgements}

The authors thank the staff at the Department of Respiration, The First Affiliated Hospital of Bengbu Medical College and Anhui Provincial Key Laboratory of Clinical Basic Research on Respiratory Disease, The First Affiliated Hospital of Bengbu Medical College. This study was supported by grants from the Natural Science Fund of the Education Department of Anhui Province (no. KJ2014A158).

\section{References}

1. Siegel RL, Miller KD and Jemal A: Cancer statistics, 2016. CA Cancer J Clin 66: 7-30, 2016.

2. De Grève J, Van Meerbeeck J, Vansteenkiste JF, Decoster L, Meert AP, Vuylsteke P, Focan C, Canon JL, Humblet Y, Berchem G, et al: Prospective evaluation of first-line erlotinib in advanced non-small cell lung cancer (NSCLC) carrying an activating EGFR mutation: A multicenter academic phase II study in Caucasian patients (FIELT). PLoS One 11: e0147599, 2016.

3. Kazandjian D, Blumenthal GM, Yuan W, He K, Keegan P and Pazdur R: FDA Approval of gefitinib for the treatment of patients with metastatic EGFR mutation-positive non-small cell lung cancer. Clin Cancer Res 22: 1307-1312, 2016.

4. Yang JC, Hirsh V, Schuler M, Yamamoto N, O'Byrne KJ, Mok TS, Zazulina V, Shahidi M, Lungershausen J, Massey D, et al: Symptom control and quality of life in LUX-Lung 3: A phase III study of afatinib or cisplatin/pemetrexed in patients with advanced lung adenocarcinoma with $E G F R$ mutations. J Clin Oncol 31: 3342-3350, 2013.
5. Shaw AT, Kim DW, Nakagawa K, Seto T, Crinó L, Ahn MJ, De Pas T, Besse B, Solomon BJ, Blackhall F, et al: Crizotinib versus chemotherapy in advanced $A L K$-positive lung cancer. N Engl J Med 368: 2385-2394, 2013.

6. Shaw AT, Kim DW, Mehra R, Tan DS, Felip E, Chow LQ, Camidge DR, Vansteenkiste J, Sharma S, De Pas T, et al: Ceritinib in $A L K$-rearranged non-small-cell lung cancer. N Engl J Med 370: 1189-1197, 2014.

7. Ou SH, Ahn JS, De Petris L, Govindan R, Yang JC, Hughes B, Lena H, Moro-Sibilot D, Bearz A, Ramirez SV, et al: Alectinib in crizotinib-refractory $A L K$-rearranged non-small-cell lung cancer: A phase II global study. J Clin Oncol 34: 661-668, 2016.

8. Rizvi NA, Mazières J, Planchard D, Stinchcombe TE, Dy GK, Antonia SJ, Horn L, Lena H, Minenza E, Mennecier B, et al: Activity and safety of nivolumab, an anti-PD-1 immune checkpoint inhibitor, for patients with advanced, refractory squamous non-small-cell lung cancer (CheckMate 063): A phase 2, single-arm trial. Lancet Oncol 16: 257-265, 2015.

9. Garon EB, Leighl NB, Rizvi NA, Blumenschein GR, Balmanoukian AS, Eder JP, Goldman JW, Hui R, Soria JC, Gangadhar TC, et al.: Safety and clinical activity of MK-3475 in previously treated patients with non-small cell lung cancer. J Clin Oncol 32: 8020, 2014.

10. Casaluce F, Sgambato A, Sacco PC, Palazzolo G, Maione P, Rossi A, Ciardiello F and Gridelli C: Emerging drugs targeting PD-1 and PD-L1: Reality or hope? Expert Opin Emerg Drugs 19: 557-569, 2014.

11. Tatarelli C, Linnenbach A, Mimori $\mathrm{K}$ and Croce CM: Characterization of the human TESTIN gene localized in the $F R A 7 G$ region at 7q31.2. Genomics 68: 1-12, 2000.

12. Tobias ES, Hurlstone AF, MacKenzie E, McFarlane R and Black DM: The TES gene at 7q31.1 is methylated in tumours and encodes a novel growth-suppressing LIM domain protein. Oncogene 20: 2844-2853, 2001.

13. Mruk DD and Cheng CY: Rat and mouse testicular testin is different from the human tumor suppressor gene TESTIN (Tes): Authors' response to the letter of Dr. S. Kapoor. Spermatogenesis 2: 305, 2012.

14. Drusco A, Zanesi N, Roldo C, Trapasso F, Farber JL, Fong LY and Croce CM: Knockout mice reveal a tumor suppressor function for Testin. Proc Natl Acad Sci USA 102: 10947-10951, 2005.

15. Chêne L, Giroud C, Desgrandchamps F, Boccon-Gibod L, Cussenot $\mathrm{O}$, Berthon $\mathrm{P}$ and Latil A: Extensive analysis of the $7 \mathrm{q} 31$ region in human prostate tumors supports TES as the best candidate tumor suppressor gene. Int J Cancer 111: 798-804, 2004.

16. Mueller W, Nutt CL, Ehrich M, Riemenschneider MJ, von Deimling A, van den Boom D and Louis DN: Downregulation of $R U N X 3$ and TES by hypermethylation in glioblastoma. Oncogene 26: 583-593, 2007.

17. Gu Z, Ding G, Liang K, Zhang H, Guo G, Zhang L and Cui J: TESTIN suppresses tumor growth and invasion via manipulating cell cycle progression in endometrial carcinoma. Med Sci Monit 20: 980-987, 2014.

18. Qiu H, Zhu J, Yuan C, Yan S, Yang Q and Kong B: Frequent hypermethylation and loss of heterozygosity of the testis derived transcript gene in ovarian cancer. Cancer Sci 101: 1255-1260, 2010.

19. Sarti M, Sevignani C, Calin GA, Aqeilan R, Shimizu M, Pentimalli F, Picchio MC, Godwin A, Rosenberg A, Drusco A, et a1: Adenoviral transduction of Testin gene into breast and uterine cancer cell lines promotes apoptosis and tumor reduction in vivo. Clin Cancer 11: 806-813, 2005.

20. Ohkouchi S, Kawamoto N, Koga M, Sakanashi F, Shichijo S, Saijo Y, Nukiwa T, Itoh K and Yamada A: Identification of a CTL-directed epitope encoded by an intron of the putative tumor suppressor gene Testin of the common fragile site $7 \mathrm{G}$ region: A peptide vaccine candidate for HLA-B52 ${ }^{+}$and HLA- $62^{+}$cancer patients. Eur J Immunol 33: 2964-2973, 2003.

21. Griffith E: Using RNA interference to knock down the adhesion protein TES. Methods Mol Biol 370: 97-108, 2007.

22. Zhu J, Li X, Kong X, Moran MS, Su P, Haffty BG and Yang Q: Testin is a tumor suppressor and prognostic marker in breast cancer. Cancer Sci 103: 2092-2101, 2012.

23. Long JG, Zhang CQ and Zhao L: Expression of Testin in human colorectal carcinoma and its clinical significance. Chin Oncol 19: 428-432, 2009 (In Chinese).

24. Yu H, Ling TS, Shu QW and Shi RH: The association of TESTIN and Caspase-3 protein expressions with clinicopathological features and prognosis of esophageal squamous cell carcinoma. Chin J Dig 30: 47-52, 2010. 
25. Weeks RJ, Ludgate JL, LeMée G and Morison IM: TESTIN induces rapid death and suppresses proliferation in childhood $\mathrm{B}$ acute lymphoblastic leukaemia cells. PLoS One 11: e0151341, 2016.

26. Dong R, Pu H, Wang Y, Yu J, Lian K and Mao C: TESTIN was commonly hypermethylated and involved in the epithelial-mesenchymal transition of endometrial cancer. APMIS 123: 394-400, 2015.

27. Huang W, Weng DS, Pan ZZ, Pan K, Ding PR, Zhou J, Wang H, Zhang HK, Li JJ and Xia JC: Expression and clinical significance of TESTIN in primary gastric cancer. Ai Zheng 27: 984-988, 2008 (In Chinese).

28. Weeks RJ, Kees UR, Song S and Morison IM: Silencing of TESTIN by dense biallelic promoter methylation is the most common molecular event in childhood acute lymphoblastic leukaemia. Mol Cancer 9: 163, 2010.

29. Zhong Z, Zhang F and Yin SC: Effects of TESTIN gene expression on proliferation and migration of the $5-8 \mathrm{~F}$ nasopharyngeal carcinoma cell line. Asian Pac J Cancer Prev 16: 2555-2559, 2015.

30. Sarti M, Pinton S, Limoni C, Carbone GM, Pagani O, Cavalli F and Catapano CV: Differential expression of testin and survivin in breast cancer subtypes. Oncol Rep 30: 824-832, 2013.

31. Garvalov BK, Higgins TE, Sutherland JD, Zettl M, Scaplehorn N, Köcher T, Piddini E, Griffiths G and Way M: The conformational state of Tes regulates its zyxin-dependent recruitment to focal adhesions. J Cell Biol 161: 33-39, 2003.

32. Coutts AS, MacKenzie E, Griffith E and Black DM: TES is a novel focal adhesion protein with a role in cell spreading. J Cell Sci 116: 897-906, 2003.

33. Griffith E, Coutts AS and Black DM: RNAi knockdown of the focal adhesion protein TES reveals its role in actin stress fibre organisation. Cell Motil Cytoskeleton 60: 140-152, 2005.

34. Freyd G, Kim SK and Horvitz HR: Novel cysteine-rich motif and homeodomain in the product of the Caenorhabditis elegans cell lineage gene lin-11. Nature 344: 876-879, 1990.

35. Karlsson O, Thor S, Norberg T, Ohlsson H and Edlund T: Insulin gene enhancer binding protein Isl-1 is a member of a novel class of proteins containing both a homeo- and a Cys-His domain. Nature 344: 879-882, 1990 .
36. Michelsen JW, Sewell AK, Louis HA, Olsen JI, Davis DR, Winge DR and Beckerle MC: Mutational analysis of the metal sites in an LIM domain. J Biol Chem 269: 11108-11113, 1994.

37. Dawid IB, Toyama R and Taira M: LIM domain proteins. C R Acad Sci III 318: 295-306, 1995.

38. Weis SM and Cheresh DA: Tumor angiogenesis: Molecular pathways and therapeutic targets. Nat Med 17: 1359-1370, 2011.

39. Scholzen T and Gerdes J: The Ki-67 protein: From the known and the unknown. J Cell Physiol 182: 311-322, 2000.

40. Stuart-Harris R, Caldas C, Pinder SE and Pharoah P: Proliferation markers and survival in early breast cancer: A systematic review and meta-analysis of 85 studies in 32,825 patients. Breast 17: 323-334, 2008.

41. He X, Chen Z, Fu T, Jin X, Yu T, Liang Y, Zhao X and Huang L: $\mathrm{Ki}-67$ is a valuable prognostic predictor of lymphoma but its utility varies in lymphoma subtypes: Evidence from a systematic meta-analysis. BMC Cancer 14: 153, 2014.

42. van Velthuysen ML, Groen EJ, van der Noort V, van de Pol A, Tesselaar ME and Korse CM: Grading of neuroendocrine neoplasms: Mitoses and Ki-67 are both essential. Neuroendocrinology 100: 221-227, 2014.

43. Berghoff AS, Ilhan-Mutlu A, Wöhrer A, Hackl M, Widhalm G, Hainfellner JA, Dieckmann K, Melchardt T, Dome B, Heinzl H, et al: Prognostic significance of Ki67 proliferation index, HIF1 alpha index and microvascular density in patients with non-small cell lung cancer brain metastases. Strahlenther Onkol 190: 676-685, 2014.

44. Del Gobbo A, Pellegrinelli A, Gaudioso G, Castellani M, Zito Marino F, Franco R, Palleschi A, Nosotti M, Bosari S, Vaira V, et al: Analysis of NSCLC tumour heterogeneity, proliferative and 18F-FDG PET indices reveals Ki67 prognostic role in adenocarcinomas. Histopathology 68: 746-751, 2016.

45. Ji Y, Zheng M, Ye S, Chen J and Chen Y: PTEN and Ki67 expression is associated with clinicopathologic features of non-small cell lung cancer. J Biomed Res 28: 462-467, 2014. 